\title{
ANALISIS STRATEGI PEMBIAYAAN DALAM UPAYA OPTIMALISASI KONSEP GREEN FINANCE (Studi Kasus Pada Bank Rakyat Indonesia Syariah Kantor Cabang Malang)
}

\author{
SRI INDAH ISTIOWATI \\ Jurusan Perbankan Syariah, Fakultas Ekonomi Universitas Islam Negeri \\ Maulana Malik Ibrahim Malang
}

\begin{abstract}
The concept of Green Finance (Triple Bottom Line), Profit, People and Planet which emphasized for optimization economic factors, attention to the sustainability of environmental factors. The community demanded that company follow concept of Green Finance to achieve environmental improvement balanced with economic development. Banks should apply concept of Green Finance to maintain environmental conditions. The purpose research is to know the application of Green Finance at Bank Rakyat Indonesia Syariah Branch Malang and optimize the existing Green Finance by using SWOT Analysis. This research use descriptive qualitative approach. Object of this study was taken at PT Rakyat Indonesia Syariah Branch Malang, uses research method, data reduction, data display, conclusion and verification. The results showed that implementation of Green Finance at Bank Rakyat Indonesia Syariah Branch Malang not only to improve the economic level of the customer, but also social awareness and environmental analysis with AMDAL. Bank Rakyat Indonesia Syariah Branch Malang have potential to became bank which to maintain economic and natural stability, and strive the needs of funds desired by customers. Bank Rakyat Indonesia Syariah Branch Malang optimize balancing aspects of people, the planet (environment), and profit (economy), in financing, Account officers keep in providing financing comfort to customer
\end{abstract}

\section{Keyword: Green Finance, Optimization, Financing Strategy, SWOT Analysis}

Abstrak. Konsep Green Finance berpijak (Triple Bottom Line) yaitu Profit, People dan Planet yang menitikberatkan tidak hanya optimalisasi faktor ekonomi, tetapi memperhatikan keberlangsungan dan kelestarian faktor lingkungan. Masyarakat menuntut perusahaan mengikuti konsep Green Finance demi tercapainya perbaikan lingkungan yang berjalan beriringan dengan berkembangnya perekonomian. Bank menerapkan konsep Green Finance demi menjaga keadaan lingkungan. Tujuan penelitian adalah untuk mengetahui penerapan Green Finance pada Bank Rakyat Indonesia Syariah Cabang Malang dan mengoptimalkan Green Finance yang sudah ada dengan menggunakan Analisis SWOT. Penelitian menggunakan pendekatan kualitatif deskriptif. Objek penelitian diambil pada PT Rakyat Indonesia Syariah Cabang Malang. Teknik analisis data menggunakan metode analisis penyajian data, reduksi data, display data, penarikan kesimpulan dan verifikasi. Hasil penelitian menunjukkan bahwa penerapan Green Finance pada Bank Rakyat Indonesia Syariah Cabang Malang bertujuan memperbaiki taraf ekonomi nasabah, dan mementingkan kepedulian sosial serta analisis lingkungan sesuai dengan AMDAL. Bank Rakyat Indonesia Syariah Cabang Malang memiliki potensi menjadi bank yang menjaga kestabilan ekonomi dan alam, serta mencukupi kebutuhan nasabah. Bank Rakyat Indonesia Syariah Cabang Malang berusaha mengoptimalkan dengan cara menyeimbangkan aspek people (masyarakat), planet (lingkungan hidup), dan profit (ekonomi), strict dalam meloloskan pembiayaan, Account Officer yang jeli dalam pemberian pembiayaan dan memberikan kenyamanan kepada nasabah pembiayaan. Kata Kunci: Green Finance, Optimalisasi, Strategi Pembiayaan, Analisis SWOT 


\section{PENDAHULUAN}

Pada abad ke-21, manusia di dunia telah mengalami perubahan yang cepat, tak terkecuali juga dengan lingkungan. Revolusi kondisi lingkungan ini mengakibatkan gejolak pergeseran paradigma. Pemanasan global dan krisis lingkungan di seluruh dunia adalah beberapa fenomena dari tahap revolusi akibat semakin berkurangnya lahan hijau (Yongrok, 2015: 14785). Sementara proses globalisasi tersebut berlanjut dengan cepat demi memenuhi kebutuhan seluruh dunia, proses ini juga membawa beberapa masalah. Dalam permasalah yang butuh ditangani salah satunya adalah masalah lingkungan (Valarmathi dan Yuvarani, 2016: 16363).

Saat ini masalah lingkungan cukup sering diperbincangkan. Sebagaimana telah diketahui bersama bahwa lapisan ozon kini semakin menipis. Dengan terus menipisnya lapisan itu, sangat dikhawatirkan bila lapisan ini tidak ada atau menghilang sama sekali dari alam semesta ini. Tanpa lapisan ozon sangat banyak akibat negatif yang akan menimpa makhluk hidup di muka bumi ini (Himpunan Pemerhati Lingkungan Hidup, 2011).

Semua akibat negatif tersebut akan semakin parah apabila tidak ada aksi nyata untuk memperbaiki kondisi lingkungan yang ada saat ini. Manusia sebagai makhluk yang derajatnya paling tinggi di antara ciptaan Allah SWT yang lain serta dibekali akal dan budi pekerti harusnya mampu menjaga kondisi lingkungan, bukan justru merusak kondisi lingkungan demi pencapaian kepentingan masing-masing. Semakin meningkat pertumbuhan penduduk maka virus ini kian mengancam keselamatan bumi, menjadikannya terpuruk oleh parasit bernama manusia. Sesungguhnya manusia itu relatif bermental buruk. Salah satunya berwatak perusak (al-fasid). Sekarang tinggal manusianya saja, mampu dan maukah menggunakan akalnya untuk melestarikan lingkungan dan tidak merusak alam? Jawabannya ada pada diri manusia itu sendiri (Subhan, 2017).

Perbankan syariah, dalam rangka mendukung perbaikan lingkungan turut serta melaksankan konsep Green Finance. Memang jika dilihat dari beberapa segi, perbankan dan lingkungan dianggap dua 'dunia' yang dalam beberapa hal cenderung berlawanan, karena Bank adalah institusi profit oriented sedangkan lingkungan adalah suatu sistem yang tidak bernilai finansial (Ayu dan Anityasari, 2013: 1).

Akan tetapi, Lako (2014) dalam bukunya Green Economy menjawab bahwa pihak perbankan memiliki peran strategis untuk mendorong perbaikan lingkungan. Perbankan memiliki otoritas untuk mendorong atau bahkan memaksa perusahaanperusahaan agar menghijaukan bisnisnya melalui kebijakan kredit kepada para nasabahnya (Lako, 2014: 93).

Depdikbud (2003) pendidikan anak usia dini adalah upaya pembinaan yang di tunjukan kepada anak sejak lahir sampai dengan usia 6 tahun yang di lakukan melalui pemberian rangsangan pendidikan untuk membantu pertumbuhan dan perkembangan jasmani dan rohani agar anak memiliki kesiapan dalam memasuki pendidikan lebih lanjut. Taman kanak-kanak adalah salah satu bentuk satuan pendidikan anak usia dini pada jalur pendidikan formal yang menyelenggakan pendidikan empat sampai enam tahun. Pendidikan anak usia dini pada jalur pendidikan formal ,nonformal berbentuk taman kanak-kanak (TK), taman penitipan anak (TPA), kelompok bermain (KB), raudatul athfal (RA), dan ketentuan-ketentuan mengenai pendidikan anak usia dini. Maka pendidikan usia dini merupakan cikal bakal generasi yang memiliki kualitas yang diharapkan oleh pendudukan jenjang yang lebih tinggi. 
Penelitian Sukoco dan Sengguruh Nilowardono (2009) mengenai analisa harapan dan persepsi pelanggan PT PLN bahwa pelanggan PLN belum merasa puas atas pelayanan Service Quality yang diberikan oleh PT. PLN (PERSERO) APJ Surabaya Utara. Penelitian Iqbal (2008) yang meneliti tentang pengaruh persepsi nilai, harapan dan kepercayaan terhadap kepuasan pelanggan dihasilkan variabel persepsi nilai dan kepercayaan memengaruhi kepuasan akan PJI secara langsung dan signifikan. Sedangkan untuk variabel harapan mempunyai pengaruh yang negatif terhadap kepuasan konsumen. Hal ini membuktikan bahwa persepsi dan harapan menghasilkan pengaruh yang berbeda dan bahkan bisa selaras, oleh karena itu persepsi dan aharapan masyarakat terhadap lembaga pendidikan swasta patut untuk diketahui guna meningkatkan kualitas pendidikan di lembaga swasta.

Di perkembangan terkini, beberapa isu tentang penjagaan lingkungan tidak hanya berkaitan dengan hal-hal materi semata, akan tetapi erat kaitannya dengan dimensi moral dan spiritual. Kamali menyebutkan beberapa pijakan dalam penjagaan lingkungan adalah tauhid (divine oneness/mengesakan Allah), khilafah (vicegerency/manusia sebagai wakil Allah), amanah (trusteeship/dapat dipercaya), umran (building the earth/memakmurkan bumi), tawazun (keeping the balance/menjaga keseimbangan), al-nadzafah wa al-jamal (beauty and cleanliness/kebersihan dan keindahan), al-intihaaq wa al-isaa'ah (violation and abuse/pelanggaran dan penyalahgunaan), fasad al-ardh (mischief making and corruption/menjauhi perusakan bumi), israf wa al-tabdzir (extravagance and waste/menjauhi berlebih-lebihan dan mubazir), al-dzarar yuzal (infliction ofharm/menghindari bahaya) (Fauzia, 2016: 91).

Berdasarkan uraian diatas, ada inconsistent hasil dari konsep Green Finance yang diterapkan di lini Perbankan, oleh karena itu penulis tertarik untuk melakukan penelitian dengan judul "Analisis Strategi Pembiayaan dalam Upaya Optimalisasi Konsep Green Finance (Studi Kasus pada Bank Rakyat Indonesia Syariah Kantor Cabang Malang)". Dengan menggunakan metode analisis SWOT (Strenght, Weakness, Opportunitiess dan Threats) diharapkan Perbankan Syariah dapat menentukan strategi bisnis pembiayaan yang tepat dan sesuai untuk dapat diimplementasikan dalam proses bisnisnya, serta meminimalkan kelemahan dan ancaman yang dialami oleh perusahaan.

Berangkat dari latar belakang di atas, maka dapat dirumuskan suatu fokus permasalahan sebagai berikut:

1. Bagaimana penerapan Green Finance di BRI Syariah Kantor Cabang Malang?

2. Bagaimana potensi dari Green Finance yang ada di BRI Syariah Kantor Cabang Malang?

3. Bagaimana mengoptimalkan konsep Green Finance di BRI Syariah Kantor Cabang Malang?

\section{KAJIAN PUSTAKA}

\section{Perbankan Syariah}

a. Indonesia adalah negara kepulauan terbesar di dunia yang memiliki beragam suku bangsa, bahasa, dan agama dengan jumlah penduduk 240 juta. Semakin majunya sistem keuangan dan perbankan serta semakin meningkatnya kesejahteraan, kebutuhan masyarakat, khususnya Muslim, menyebabkan semakin besarnya kebutuhan terhadap layanan jasa perbankan yang sesuai dengan prinsip syariah (Ascarya, 2015: 203).

b. Definisi Pembiayaan

1. Pembiayaan atau finance, yaitu pendanaan yang diberikan oleh suatu pihak kepada pihak lain untuk mendukung investasi yang telah direncanakan, baik dilakukan sendiri maupun lembaga. Dalam kaitannya dengan 
pembiayaan pada perbankan Islam atau istilah teknisnya disebut sebagai aktiva produktif. Aktiva produktif adalah penanaman dana Bank Islam baik dalam rupiah maupun valuta asing dalam bentuk pembiayaan, piutang, qardh, surat berharga Islam, penempatan modal, penyertaan modal sementara, komitmen, dan kontijensi pada rekening administrasi serta sertifikat wadiah (Rivai, 2010: 681).

2. Ada pula pengertian pembiayaan menurut Kasmir adalah penyediaan uang atau tagihan yang dapat dipersamakan dengan itu, berdasarkan persetujuan atau kesepakatan antara bank dengan pihak lain yang mewajibkan pihak yang dibiayai untuk mengembalikan uang atau tagihan tersebut setelah jangka waktu tertentu dengan imbalan atau bagi hasil (Kasmir, 2014: 82).

\section{Prinsip Pembiayaan}

Adapun prinsip- prinsip dari pembiayaan adalah (Asiyah, 2015: 82):

1. Prinsip $5 \mathrm{C}$

a) Character

Character menggambarkan watak dan kepribadian calon debitur. Bank perlu melakukan analisis terhadap karakter calon nasabah, tujuannya adalah untuk mengetahui bahwa calon nasabah mempunyai keinginan untuk memenuhi kewajiban membayar pinjamannya sampai dengan lunas.

b) Capacity

Analisis terhadap capacity ini ditujukan untuk mengetahui kemampuan calon nasabah dalam memenuhi kewajibannya sesuai jangka waktu pembiayaan. Bank perlu mengetahui dengan pasti kemampuan calon nasabah tersebut.

c) Capital

Capital atau modal yang perlu disertakan dalam objek pembiayaan perlu dilakukan analisis yang lebih mendalam. Modal merupakan jumlah modal yang dimiliki oleh calon nasabah atau berapa banyak dana yang akan diikutsertakan dalam proyek yang dibiayai oleh calon nasabah.

d) Collateral

Berdasarkan ketentuan yang dikeluarkan pemerintah/Bank Indonesia, setiap pemberian kredit atau pembiayaan oleh bank harus didukung oleh adanya jaminan/agunan yang memadai, kecuali untuk program-program pemerintah.

e) Condition of Economy

Condition of economy merupakan analisis terhadap kondisi perekonomian. Bank perlu mempertimbangkan sektor usaha calon nasabah dikaitkan dengan kondisi ekonomi, apakah kondisi ekonomi tersebut akan berpengaruh pada usaha calon nasabah di masa yang akan datang.

Dari analisis tersebut, akan diperoleh gambaran tentang nasabah dan kemungkinan pembiayaannya (Asiyah, 2015: 89). Ada pula mengenai prinsip $5 \mathrm{P}$, yaitu (Asiyah, 2015: 91):

a) Party (Golongan)

Bank mencoba melakukan penilaian terhadap beberapa golongan yang terdiri dari golongan yang sesuai dengan character, capacity, capital. Bank akan melihat ketiga prinsip tersebut dalam mengambil keputusan pembiayaan, karena ketiga prinsip tersebut merupakan prinsip minimal yang harus dianalisis oleh bank sebelum memutuskan pembiayaan yang diajukan oleh calon nasabah.

b) Purpose (Tujuan) 
Purpose lebih difokuskan terhadap tujuan penggunaan pembiayaan yang diajukan oleh calon nasabah. Bank akan melihat dan melakukan analisis terhadap tujuan pembiayaan tersebut dengan mengkaitkannya dengan beberapa aspek sosial lainnya.

c) Payment (Pembayaran Kembali)

Sebelum memutuskan permohonan pembiayaan nasabah, maka yang perlu dilakukan oleh bank adalah menghitung kembali kemampuan calon nasabah dengan melakukan estimasi terhadap pendapatan dan biaya.

d) Profitability (Kemampuan Perusahaan dalam Memperoleh Keuntungan)

Profitability, tidak terbatas pada keuntungan calon nasabah, akan tetapi juga keuntungan yang akan dicapai oleh bank apabila pembiayaan tersebut diberikan.

e) Protection (Perlindungan)

Proteksi merupakan upaya perlindungan yang dilakukan bank dalam rangka berjaga-jaga apabila calon nasabah tidak dapat memenuhi kewajibannya.

\section{Analisis SWOT}

Analisis SWOT adalah identifikasi berbagai faktor secara sistematis untuk merumuskan strategi perusahaan. Analisis ini didasarkan pada logika yang dapat memaksimalkan kekuatan (strenght) dan peluang (opportunities), namun secara bersamaan dapat meminimalkan kelemahan (weakness) dan ancaman (treats). Proses pengambilan keputusan strategis selalu berkaitan dengan pengembangan misi, tujuan, strategi, dan kebijakan perusahaan. Dengan demikian perencanaan strategis (strategic planner) harus menganalisis faktor-faktor strategis perusahaan (kelemahan, kekuatan, peluang dan ancaman) dalam kondisi yang ada saat ini. Hal ini disebut dengan Analisis Situasi. Model yang paling populer untuk analisis situasi adalah Analisis SWOT (Rangkuti, 2001: 19).

Analisis SWOT yakni mencakup upaya-upaya untuk mengenali kekuatan, kelemahan, peluang, dan ancaman yang menentukan kinerja perusahaan. Informasi eksternal mengeni peluang dan ancaman dapat diperoleh dari banyak sumber, termasuk pelanggan, dokumen pemerintah, pemasok, kalangan perbankan, rekan diperusahaan lain. Banyak perusahaan menggunakan jasa lembaga pemindaian untuk memperoleh keliping surat kabar, riset di internet, dan analisis trentrendomestik dan global yang relevan (Richard L. Daft 2010: 253).

Penelitian menunujukkan bahwa kinerja perusahaan dapat ditentukan oleh kombinasi faktor internal dan eksternal. Kedua faktor tersebut harus dipertimbangkan dalam analisis SWOT. SWOT adalah singkatan dari lingkungan Internal Strengths dan Weakness serta lingkungan eksternal Opportunities dan Threats yang dihadapi dunia bisnis. Analisis SWOT membandingkan antara faktor eksternal Peluang (Opportunities) dan Ancaman (Threats) dengan faktor internal Kekuatan (Strengths) dan (Weakness) (Rangkuti, 2001: 20).

\section{METODE PENELITIAN}

\section{Ruang Lingkup Penelitian}

Jenis penelitian ini adalah penelitian kualitatif dengan metode studi kasus dalam menghimpun, mengambil, dan memperoleh data yang di butuhkan. Studi kasus merupakan salah satu jenis pendekatan kualiatatif yang menelaah sebuah "kasus" tertentu dalam konteks atau setting kehidupan nyata kontemporer (Creswell, 2015: 9). Dalam penelitian mengenai Green Finance berlokasi di salah satu Bank Umum Syariah yang berada di Kota Malang yaitu pada Bank Rakyat Indonesia Syariah Kantor Cabang Malang. 


\section{Metode dan Teknik}

Dalam penelitian ini menggunakan teknik snowball sampling, teknik pengambilan sumber data yang pada awalnya jumlahnya sedikit, lama-lama menjadi besar. Hal ini dilakukan karena dari sumber data yang sedikit tersebut belum mampu memberikan data yang memuaskan, maka mencari orang lain yang dapat digunakan sebagai sumber data (Sugiono, 2008: 42). Pengumpulan data yang dibutuhkan dalam penelitian ini dilakukan dengan cara sebagai berikut (Azwar, 2007) yaitu wawancara, observasi lapangan dan dokumentasi.

\section{Proses Pengumpulan Data}

Penelitian ini menggunakan metode studi kasus. Diantara tahapan- tahapan yang dapat dijabarkan adalah sebagai berikut (Sugiono, 2008: 46):

1. Penyajian Data

2. Reduksi Data

3. Display Data

4. Penarikan Kesimpulan dan Verifikasi

\section{HASIL DAN PEMBAHASAN}

\section{Hasil Penelitian}

\section{a. Penerapan Green Finance di BRI Syariah Kantor Cabang Malang}

Berdasarkan hasil wawancara dengan Pak Irawan selaku Financing Support PT. Bank Rakyat Indonesia Syariah Cabang Malang pada tanggal 4 September 2017 pukul 13.45 WIB tentang pengertian dan tujuan dari Green Finance di BRISyariah adalah sebagai berikut:

"Pembiayaan Green Finance itu di kami masuk ke dalam akad Musyarakah mbak. Ya, soalnya disitu ada konstribusi modal antara bank dengan nasabah. Kalau untuk proporsi ya tergantung kesepakatan antara bank dengan nasabah di awal. Bank tidak menentukan harus seberapa banyak modal dari pihak nasabah".

Konsep Green Finance di Bank Rakyat Indonesia Syariah sebenarnya sudah digadang-gadang muncul sejak tahun 2015. Hal ini juga di buktikan oleh data yang ada di Annual Report Bank Rakyat Indonesia Syariah di tahun 2015 mengenai kesadaran akan pentingnya menjaga kelestarian lingkungan.

\section{b. Potensi Green Finance di BRI Syariah Kantor Cabang Malang}

Berdasarkan hasil wawancara tersebut Bank Rakyat Indonesia Syariah dalam menjalankan pembiayaan Green Finance lebih mengarah pada pembiayaan modal kerja untuk pengelolaan komoditas dari nasabah dibandingkan mereka harus membeli tanah saja. Pertimbangan atas hal tersebut ialah bank tidak akan tahu produktivitas atas tanah dari nasabah sehingga rentan akan risiko gagal bayar dari pihak nasabah apabila tidak ada hasil panen dari tanah yang sudah di berikan pembiayaan tersebut. Pemberiaan pembiayaan Green Finance dengan akad musyarakah pada BRISyariah lebih banyak diperuntukkan untuk pengolahan barang komoditasnya ketimbang pada lahannya.

Dalam pembiayaan Green Finance Bank Rakyat Indonesia Syariah telah melakukan pembiayaan di bidang perkebunan yaitu untuk membiayai kelapa sawit, kopi dan karet. Sebelum memberikan pembiayaan Green Finance tersebut kepada nasabahnya, Bank Rakyat Indonesia Syariah melakukan Feasibility Study. Feasibility Study merupakan sebuah kegiatan yang bertujuan untuk menganalisis sebuah bisnis yang meliputi keuntungan perusahaan, maupun keuntungan yang akan diperoleh oleh masyarakat sekitar jika sebuah bisnis tersebut dijalankan.

\section{c. Optimalisasi Green Finance di BRI Syariah Kantor Cabang Malang}


Tabel 1. Faktor Internal dan Eksternal

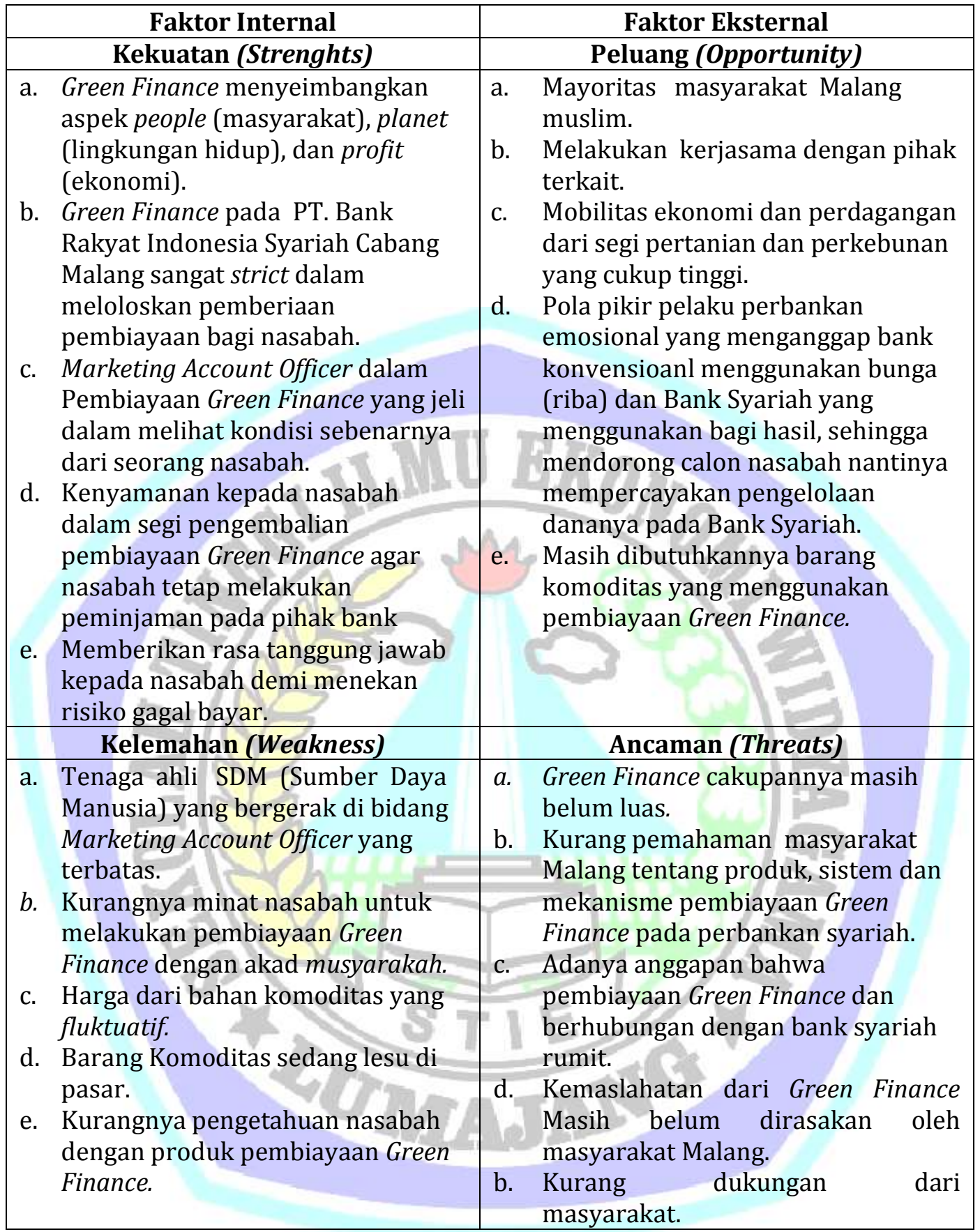

Sumber : Hasil Olahan Penulis Tahun 2017

d. Strategi Optimalisasi pada PT. Bank Rakyat Indonesia Syariah Cabang Malang

Tabel 2. Internal Factor Analysis Summary (IFAS)

\begin{tabular}{|c|l|l|l|l|}
\hline $\begin{array}{c}\text { Faktor-Faktor } \\
\text { Internal } \\
\text { (Strenght) dan } \\
\text { (Weakness) }\end{array}$ & Bobot & Rating & Nilai Skor & Keterangan \\
\hline $1 . \quad \begin{array}{l}\text { Green Finance } \\
\text { menyeimbangkan }\end{array}$ & 0,10 & 4 & 0,40 & 1. Citra perusahaan \\
\hline
\end{tabular}




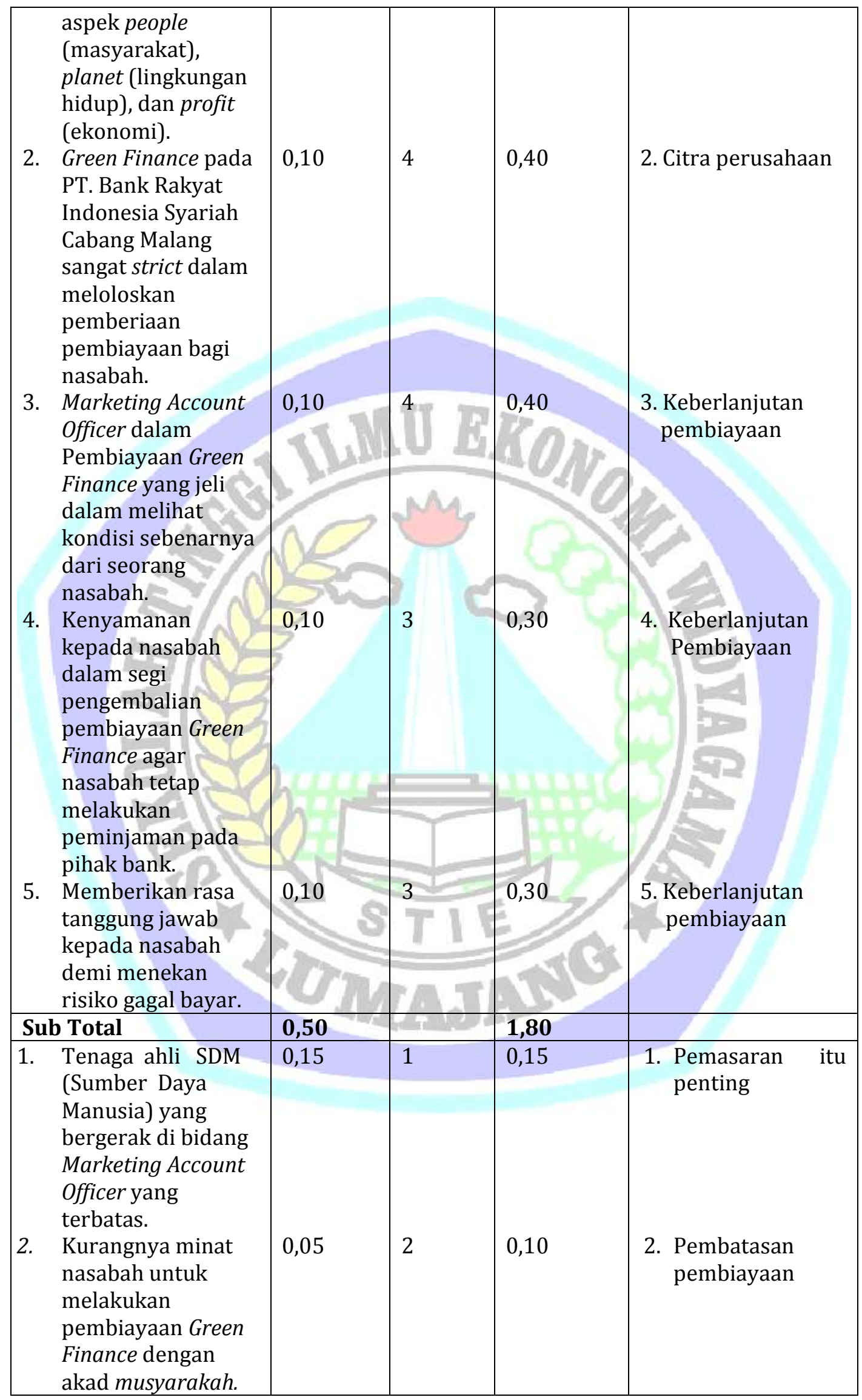




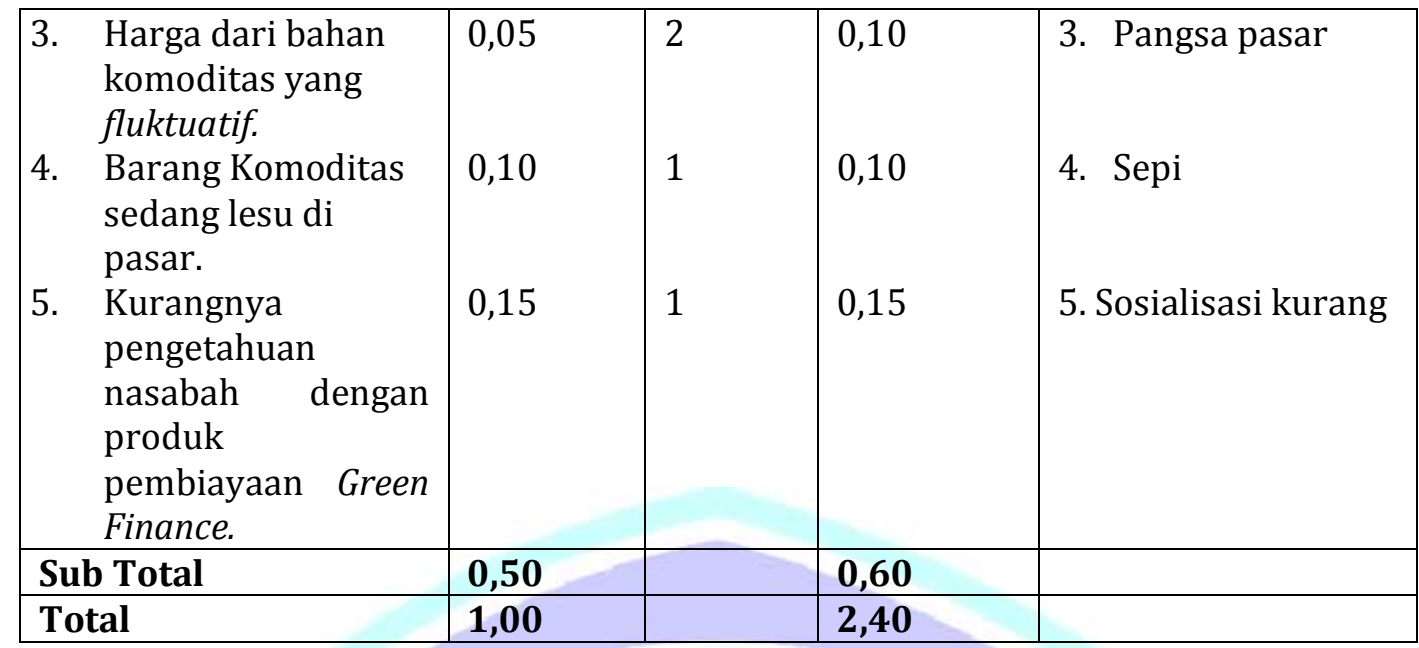

Sumber : Hasil Pengolahan Data Penulis Tahun 2017

Tabel 3. Eksternal Factor Analysis Summary (EFAS)

\begin{tabular}{|c|c|c|c|c|c|}
\hline & $\begin{array}{c}\text { Faktor-Faktor } \\
\text { Eksternal } \\
\text { (Opportunity) dan } \\
\text { (Threats) }\end{array}$ & Bobot & Rating & $\mathrm{Ni}$ & Keterangan \\
\hline 1. & $\begin{array}{l}\text { Mayoritas } \\
\text { masyarakat Malang } \\
\text { muslim. }\end{array}$ & & 4 & & 1. 1.Peluang besar \\
\hline 2. & $\begin{array}{l}\text { Melakukan } \\
\text { kerjasama dengan } \\
\text { pihak terkait. }\end{array}$ & 0,10 & 4 & 0,40 & 2. Link \\
\hline 3. & $\begin{array}{l}\text { Mobilitas ekonomi } \\
\text { dan perdagangan } \\
\text { dari segi pertanian } \\
\text { dan perkebunan } \\
\text { yang cukup tinggi. }\end{array}$ & 0,10 & 4 & 0,40 & $\begin{array}{l}\text { 3. Keberlanjutan } \\
\text { pembiayaan }\end{array}$ \\
\hline 4. & $\begin{array}{l}\text { Pola pikir pelaku } \\
\text { perbankan } \\
\text { emosional yang } \\
\text { menganggap bank } \\
\text { konvensioanl } \\
\text { menggunakan bunga } \\
\text { (riba) dan Bank }\end{array}$ & & & 0 , & $\begin{array}{l}\text { 4. Keberlanjutan } \\
\text { pembiayaan }\end{array}$ \\
\hline 5. & $\begin{array}{l}\text { Syariah yang } \\
\text { menggunakan bagi } \\
\text { hasil, sehingga } \\
\text { mendorong calon } \\
\text { nasabah nantinya } \\
\text { mempercayakan } \\
\text { pengelolaan dananya } \\
\text { pada Bank Syariah. } \\
\text { Masih } \\
\text { dibutuhkannya } \\
\text { barang komoditas } \\
\text { yang menggunakan }\end{array}$ & 0,10 & 4 & 0,40 & $\begin{array}{l}\text { 5. Kesempatan } \\
\text { pembiayaan }\end{array}$ \\
\hline
\end{tabular}




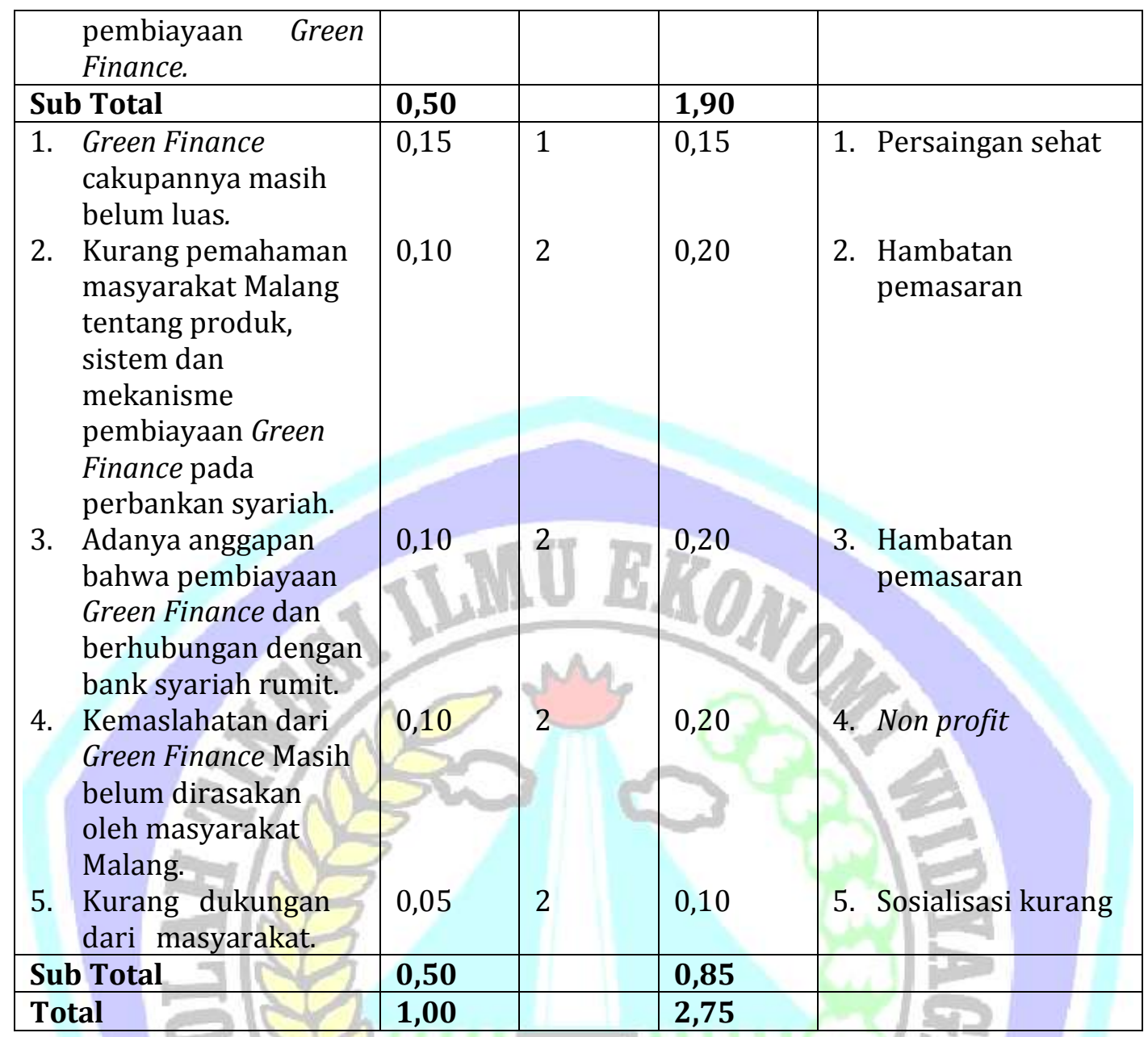

Sumber : Hasil Pengolahan Data Penulis Tahun 2017

Tabel 4. Rekap Skor IFAS dan EFAS

\begin{tabular}{|l|l|l|}
\hline \multicolumn{1}{|c|}{ Skor Internal } & \multicolumn{1}{c|}{ Skor Eksternal } & \multicolumn{1}{c|}{ Pilihan Strategi } \\
\hline$S>W(+)$ & $O>T(+)$ & GROWHT \\
$1,80>0,60(+)$ & $1,90>0,85(+)$ & \\
\hline$S<W(-)$ & $O<T(-)$ & SURVIVAL \\
\hline$S>W(+)$ & $O<T(-)$ & DIVERSIFICATION \\
\hline$S>W(-)$ & $O>T(+)$ & STABILITY \\
\hline
\end{tabular}

Gambar 1. Kuadran SWOT

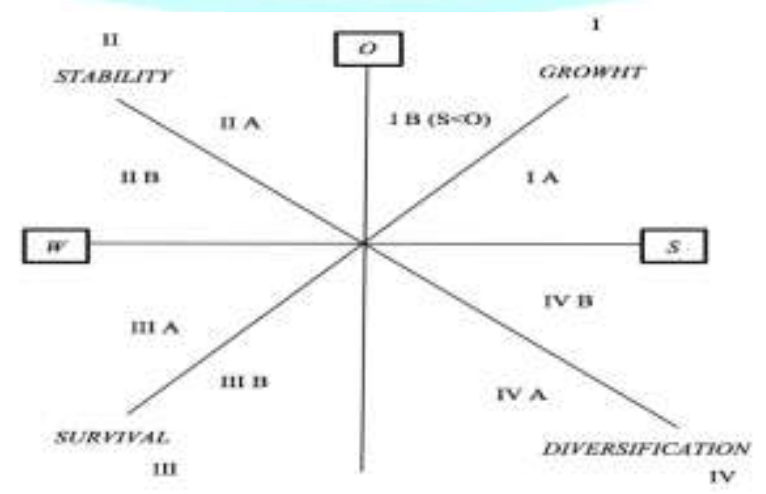


Tabel 5. Pilihan Strategi

\begin{tabular}{|l|l|l|l|}
\hline $\begin{array}{l}\text { Teknis } \\
\text { Strategis }\end{array}$ & Skor & Kuadran & Pilihan Strategi \\
\hline Growth & $S>O$ & I A & Rapid Growth \\
\hline & $S<O$ & I B & Stable Growth \\
\hline Survival & $W>T$ & III A & Turn Around \\
\hline & $W<T$ & III B & Guerilla \\
\hline Diversification & $S>T$ & IV B & Conglomerate \\
\hline & $S<T$ & IV A & Concerintric \\
\hline Stability & $O>W$ & II A & Agressive Maintenance \\
\hline & $O<W$ & IIB & Selective Maintenance \\
\hline
\end{tabular}

HASIL DAN PEMBAHASAN

Pembahasan Hasil Penelitian

Penerapan Green Finance di Bank Rakyat Indonesia (BRI) Syariah Kantor Cabang Malang

Pelaksanaan Green Finance yang bertujuan bukan hanya untuk memperbaiki taraf ekonomi dari nasabah, akan tetapi juga mementingkan kepedulian sosial serta analisis lingkungan yang sesuai dengan AMDAL. Bank Rakyat Indonesia Syariah Kantor Cabang Malang dalam menjalankan pembiayaan Green Finance lebih mengarah pada pembiayaan modal kerja untuk pengelolaan komoditas dari nasabah dibandingkan mereka harus membeli tanah saja. Dalam pembiayaan Green Finance Bank Rakyat Indonesia Syariah kantor Cabang Malang telah melakukan pembiayaan di bidang perkebunan yaitu untuk membiayai kelapa sawit, kopi dan karet. Sebelum memberikan pembiayaan Green Finance tersebut kepada nasabahnya, Bank Rakyat Indonesia Syariah melakukan Feasibility Study. Pada pembiayaan Green Finance, PT. Bank Rakyat Indonesia Syariah Cabang Malang sangat strict dalam meloloskan pemberiaan pembiayaan bagi nasabah proyek ramah lingkungan. Penyaluran pembiayaan tidak boleh diberikan apabila berdampak buruk terhadap lingkungan. Bank Rakyat Indonesia Syariah melakukan semua analisa kepada semua aspek dan menentukan kriteria nasabah yang layak diberikan pembiayaan dengan tujuan memberikan kemudahan Marketing Account Officer untuk mengambil keputusan dalam meloloskan atau tidaknya sebuah pembiayaan. Dalam hal ini, kejelian atas kinerja Marketing Account Officer untuk melihat nasabah diuji kebenarannya. Bank Rakyat Indonesia Syariah berusaha memberikan kenyamanan kepada dalam segi pembayaran pengembalian agar nasabah tetap melakukan peminjaman pada pihak bank. Dengan akad musyarakah, nasabah bisa memberikan pengembalian pembiayaan secara fleksibel. BRISyariah sangat strict terhadap pembiayaan Green Finance demi mengantisipasi timbulnya masalah di kemudian hari. BRISyariah juga melakukan studi kelayakan bisnis dari nasabah. Hal ini dilakukan untuk menilai usaha dari nasabah tersebut layak atau tidak untuk proyek itu dijalankan dan diberi pembiayaan.

\section{Potensi dari Green Finance yang ada di Bank Rakyat Indonesia (BRI) Syariah Kantor Cabang Malang}

Bank Rakyat Indonesia Syariah Cabang Malang sebagai bank yang berpotensi menjaga kestabilan ekonomi dan alam. Potensi terkait sumber dana, pembiayaan BRISyariah Cabang Malang berusaha untuk mencukupi kebutuhan dana yang diinginkan oleh nasabah pembiayaan demi terlaksananya sebuah usaha yang diinginkan oleh nasabah. Potensi yang bisa dilihat dari sebuah kegiatan penyaluran 
pembiayaan yang dilakukan oleh Bank Rakyat Indonesia Syariah Cabang Malang salah satunya adalah tidak terjadinya gagal bayar oleh nasabah serta keberhasilan dari nasabah dalam menjalankan usahanya. Potensi dari jelinya Marketing Account officer dalam meloloskan pembiayaan. Hal ini berepengaruh terhadap tingkat kepercayaan nasabah apabila akan melakukan pembiayaan di BRISyariah. Dalam pembiayaan, potensi dari Green Finance yang ada di BRISyariah adalah sistem pengembalian atas pembiayaan yang telah diberikan.

\section{Pengoptimalan konsep Green Finance di Bank Rakyat Indonesia (BRI) Syariah Kantor Cabang Malang}

PT. Bank Rakyat Indonesia Syariah Cabang Malang memiliki kemampuan untuk memperluas peran serta memanfaatkan berbagai peluang. Arah kebijakan tersebut merupakan dasar dari kebijakan dalam kondisi growth strategy dan setelah dilihat dari pilihan strategi berdasarkan pada stable growth strategy, artinya dalam optimalisasi pembiayaan Green Finance PT. Bank Rakyat Indonesia Syariah Cabang Malang dapat menggunakan strategi pertumbuhan peran namun dilakukan secara bertahap sesuai skala prioritas. Strategi tersebut didukung dengan adanya alternatif dan peluang untuk menarik nasabah yang lebih banyak dengan melakukan pengembangan layanan pembiayaan Green Finance untuk memuaskan nasabahnya. Aspek yang perlu dilakukan untuk pengembangan layanan pembiayaan Green Finance pada PT. Bank Rakyat Indonesia Syariah Cabang Malang yaitu dengan bagi hasil yang dijanjikan, menjaga reputasi yang baik, dan kejelasan dari pembiayaan yang disalurkan. Sehingga arah kebijakan yang tepat untuk dilaksanakan adalah dengan meningkatkan dan memperbesar peranan pembiayaan Green Finance pada PT. Bank Rakyat Indonesia Syariah Cabang Malang.

\section{PENUTUP}

\section{Simpulan}

1. Penerapan dari Green Finance di BRI Syariah Kantor Cabang Malang bertujuan bukan hanya untuk memperbaiki taraf ekonomi dari nasabah, akan tetapi juga mementingkan kepedulian sosial serta analisis lingkungan yang sesuai dengan AMDAL. Dengan landasan untuk memperbaiki taraf perekonomian dengan tetap memperdulikan lingkungan dan sosial, pembiayaan BRISyariah lebih mengarah pada pemberiaan pembiayaan Green Finance dengan akad musyarakah untuk pengolahan barang komoditasnya ketimbang pada pembelian lahan. kepada semua aspek dan menentukan kriteria nasabah yang layak diberikan pembiayaan.

2. Potensi dari Green Finance yang ada di BRISyariah Kantor Cabang Malang merupakan bank yang berpotensi menjaga kestabilan ekonomi dan alam, serta berusaha untuk mencukupi kebutuhan dana yang diinginkan oleh nasabah pembiayaan demi terlaksananya sebuah usaha yang diinginkan oleh nasabah.

3. Pengoptimalan konsep Green Finance di BRISyariah Kantor Cabang Malang melalui analisis SWOT dengan melakukan analisis faktor internal dan faktor eksternal pada pembiayaan Green Finance di PT. Bank Rakyat Indonesia Syariah Cabang Malang adalah:

\begin{tabular}{|l|ll|}
\hline \multicolumn{1}{|c|}{ Faktor Internal } & \multicolumn{1}{c|}{ Faktor Eksternal } \\
\hline \multicolumn{1}{|c|}{ Kekuatan (Strenghts) } & \multicolumn{1}{c|}{ Peluang (Opportunity) } \\
\hline $\begin{array}{l}\text { 1. Green Finance menyeimbangkan } \\
\text { aspek people (masyarakat), planet } \\
\text { (lingkungan hidup), dan profit }\end{array}$ & 1. & $\begin{array}{l}\text { Mayoritas masyarakat Malang } \\
\text { muslim. }\end{array}$ \\
\hline
\end{tabular}




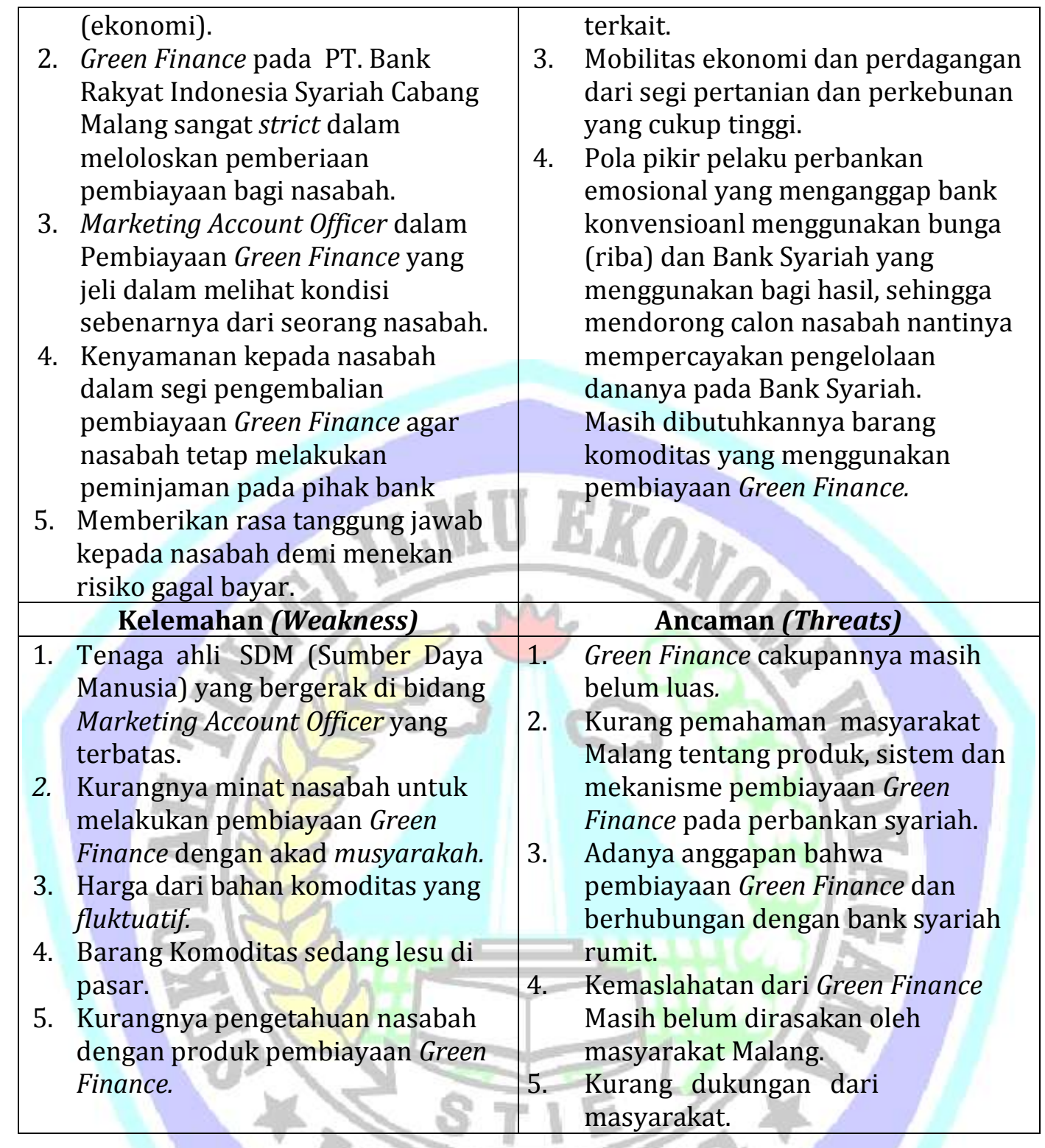

\section{Saran}

Berdasarkan hasil penelitian yang sudah dilakukan, peneliti berpendapat bahwa PT. Bank Rakyat Indonesia Syariah Cabang Malang memiliki kemampuan untuk merubah potensi-potensi yang ada di pembiayaan Green Finance menjadi suatu prestasi dan kineja yang lebih baik. Sehingga arah kebijakan yang tepat untuk dilaksanakan adalah dengan meningkatkan dan memperbesar peranan pembiayaan Green Finance pada PT. Bank Rakyat Indonesia Syariah Cabang Malang dalam berbagai kegiatan yang sesuai dengan kemampuan yang dimiliki, sekaligus untuk memperluas peran serta memanfaatkan berbagai peluang yang ada.

Sehingga untuk peneliti yang berikutnya, untuk mengetahui strategi untuk mengoptimalkan pembiayaan Green Finance pada perbankan khususnya pada perbankan syariah. Seharusnya menambah objek penelitian lebih dari satu bank untuk melihat hasil yang konkrit, serta untuk menghasilkan data yang lebih objektif, selain pihak manajemen peneliti selanjutnya sebaiknya melibatkan nasabah perbankan syariah sebagai penguat dari hasil penelitian yang sudah dilakukan. 


\section{DAFTAR RUJUKAN}

Anshori, Abdul Ghofur. 2015. Hukum Perbankan Syariah (UU No. 21 Tahun 2008). Yogyakarta: Refika Aditama.

Asiyah, Binti Nur. 2015. Manajemen Pembiayaan Bank Syariah. Yogyakarta: Kalimedia.

Arikunto, Suharsimi. 2002. Prosedur Penelitian : Sebuah Pendekatan Praktek,ed 5. Jakarta: Rineka Citra.

Ascarya. 2015. Akad dan Produk Bank Syariah. Jakarta: PT Raja Grafindo Persada

Asy-Syafii', Imam Muhammad bin Idris. 1997. Al-Asybah Wan Nazhair. Mekah Riyadh - Arab Saudi: Maktabah Nazzar Al-Baz.

Ayu, Andi Nurul Fadhilah dan Anityasari, Maria. Analisis Implementasi Green Banking pada PT. Bank X (Persero) Tbk. Jurnal Teknik Pomits Vol. 1, No. 1, (2013) 1-6.

Azwar, Saifuddin. 2007. Metode Penelitian. Yogyakarta: Pustaka Belajar.

Creswell, John W. 2015. Penelitian Kualitatif \& Desain Riset Memilih Diantara Lima Pendekatan. Yogyakarta: Pustaka Pelajar

Chowdhury, Tasnim, dkk, Green finance Is Essential For Economic Development And Sustainability. International Journal of Research In Commerce, Economics \& Management. Volume No. 3 (2013), Issue No. 10 (October). ISSN 2231-4245.

Djamil, Faturrahman. 2012. Penyelesaian Pembiayaan Bermasalah di Bank Syariah. Jakarta: Sinar Grafika

Fadhilah, Andi Nurul dan Maria Anityasari. Analisis Green Banking pada PT BANK X (Persero) Tbk. Jurnal Teknik Pomits Vol. 1, No. 1, (2013) 1-6

Fandeli, Chafid. 2007. Analisis Mengenai Dampak Lingkungan Prinsip Dasar Dalam Pembangunan. Yogyakarta: Liberty Offset

Ginting, Perdana. 2007. Sistem Pengelolaan Lingkungan dan Limbah Industri. Bandung: Yrama Widya.

Goel, Priyanka. Green Finance: A Step Towards Sustainable Financial System. Abhinav International Monthly Refereed Journal of Research in Management \& Technology. Volume 5, Issue 3 (March, 2016) ISSN-2320-0073.

Institute for Essential Services Reform (IESR). 2016. Laporan FGD Pangan dan Perubahan Iklim.

Kasmir. 2014. Manajemen Perbankan. Jakarta: PT. Raja Grafindo Persada

Keerthi. A Study on Emerging Green Finance in India: Its Challeges and Oppurtunities Research scholar, School of Commerce \& International business. International 
Journal of Management and Social Sciences Research (IJMSSR) ISSN: 2319-4421 Volume 2, No. 2, February 2013

Lako, Andreas. 2014. Green Economy Menghijaukan Ekonomi, Bisnis, \& Akuntansi. Jakarta: Erlangga. International Multidiciplinary E-Journal ISSN: 2277- 4262.

Masukujjaman, Mohammad, dkk. Bankers' perception of Green Banking: Learning from the experience of Islamic banks in Bangladesh. GEOGRAFIA OnlineTM Malaysian Journal of Society and Space 12 issue 2 (144 - 153, Themed issue on contemporary financial, business, investment and entrepreneurial facets of Malaysia's development (C) 2016, ISSN 2180-2491

Nagarjuna, Loluru. Green Financial Management Practices in the Public and Private sector Banks - a Case study of SBI \& ICICI.

OJK. 2015. Roadmap Keuangan Berkelanjutan di Indonesia. Jakarta: OJK

Oh, Deokkyo. Green Finance in Korea. Research Fellow at Korea Corporate Governance Service.

Rangkuti, Freddy. 2001. Analisis SWOT Teknik Membedah Kasus Bisnis Reorientasi Konsep Perencanaan Strategis Untuk Menghadapi Abad 2. Jakarta: PT Gramedia Pustaka Utama

Rivai, Veithzal. 2010. Islamic Banking: Sistem Bank Islam Bukan Hanya Solusi Menghadapi Krisis Namun Solusi Dalam Menghadapi Berbagai Persoalan Perbankan \& Ekonomi Global. Jakarta: Bumi Aksara

Sugiyono. 2008. Metode Penelitian Kualitatif Kuantitatif dan R\&D. Bandung: Alfabeta

Sumantri, Arif. 2010. Kesehatan Lingkungan \& Perspektif Islam. Jakarta: Kencana Prenada Media Grup

Tripti Chopra and Punit Kakrecha. Green Finance: The Practices of Banks and Perspective of Customers. International Journal of Research -Granthaalayah. Chopra et.al., Vol.3(Iss.5): May, 2015 ISSN-2350-0530(0) ISSN- 2394-3629(P)

Uddin, Nazim. Shari'ah Based Banking and Green Financing: Evidence from Bangladesh. IOSR Journal of Business and Management (IOSR-JBM) e-ISSN: 2278-487X, p-ISSN: 2319-7668. Volume 18, Issue 1.Ver. III (Jan. 2016), PP 7990 DOI: $10.9790 / 487 X-18137990$

Valarmathi and Yuvarani. SWOT Analysis And Strategies Of Green Marketing. Available Online through Research Article Department of Commerce, Trinity College for Women, Sanyasikaradu, Mohanur Road, Namakkal - 637 001, Tamil Nadu, India. 2Department of Commerce, Kailash Women's College, Nangavalli, Salem - 636 502, Tamil Nadu, India ISSN: 0975-766X.

Vyas, Manmohan. Green Finance and Sustainable Development: An Indian Perspective. International Journal of Multifaceted And Multilingual Studies. Volume-Iv, IssueVi, ISSN (Online): 2350-0476. 
Wahyudin, Dian. Strategi Konsep Ekonomi Hijau Sebagai Suistainable Development Goals Di Indonesia. Volume III, No. 01, Februari 2016 ISSN 2355-2883.

Volz, Ulrich. 2016. Fostering Green Finance for Sustainable Development in Asia. German: Deutsches Institut für Entwicklungspolitik (DIE)

Yongrok, Choi. Article Intermediary Propositions for Green Growth with Sustainable Governance. Department of International Trade and Regional Studies, Inha University, Academic Editors: Giuseppe Ioppolo, Malin Song and Seunghwan Myeong - sustainability ISSN 2071-1050

Zhou, Jiping. Research on the Development of Green Finance in Shenzhen to Boost the Carbon Trading Market. MSETEE 2017 IOP Publishing IOP Conf.

Bmkg.go.id, 2015-2016 diakses pada tanggal 28 Agustus 2017 pukul 20.43 WIB.

Himpunan Pemerhati Lingkungan Hidup Indonesia.org, 2 Desember 2011 diakses pada tanggal 18 Mei 2017 pukul 14.42 WIB

Beta, 2017. Kompasiana.com, 22 April 2017 diakses pada tanggal 05 Januari 2017 pukul 20.50 WIB 